SPORTIVE: Journal of Physical Education, Sport and Recreation
Volume 2 Nomor 2 Maret 2019
e-ISSN: $2597-7016$ dan p-ISSN: $2595-4055$
@e) (1) This work is licensed under a Creative Commons Attribution
4.0 International License

\title{
Pengaruh Latihan Sirkuit Training Terhadap Kecepatan Tendangan Sabit Pada Siswa Ekstrakulikuler Pencak Silat
}

\author{
Widati Amalin Ulfah ${ }^{1}$, Erick Prayogo Walton ${ }^{2}$
}

Keywords :

Pencak Silat;

Kecepatan Tendangan;

Sirkuit Training;

\section{Corespondensi Author}

${ }^{1}$ STKIP Muhammadiyah

Bangka Belitung,

Email:

widati.amalinulfah@stkipmbb.ac.id

Article History

Received: 26-01-2019;

Reviewed: 12-02-2019;

Accepted: 22-02-2019;

Published: 28-02-2019.

\begin{abstract}
Abstrak. Sirkuit training merupakan salah satu bentuk latihan yang dilakukan dalam satu putaran melewati beberapa pos, pada setiap pos siswa melakukan berbagai bentuk latihan yang bervariasi dan dilakukan secara berulang-ulang. Tujuan penelitian ini adalah untuk mengetahui hasil peningkatan kecepatan tendangan sabit pada siswa ekstrakulukuler pencak silat SMP Negeri 2 pangkalpinang. Jenis penelitian yang digunakan adalah penelitian kuantitatif. Desain penelitian eksperimental yang digunakan adalah pretest dan posttest control group design. Populasi terdiri dari 28 siswa dengan teknik pengambilan sampel yaitu menggunakan teknik total sampling. Setelah semua data dianalisis dengan berbagai tahapan yang dimulai dari uji statistika untuk menentukan mean, median, modus, standar deviasi, varian dan range. Kemudian dilakukan uji normalitas, uji homogenitas dan uji hipotesis dengan syarat $t_{\text {hitung lebih besar dari }}$ $t_{\text {tabel. }}$. Berdasarkan perhitungan diketahui bahwa $t_{\text {hitung }}=$ $3,483>2,056$, maka dapat disimpulkan bahwa ha diterima, artinya bahwa terdapat pengaruh latihan sirkuit training terhadap kecepatan tendangan sabit pencak silat.
\end{abstract}

\section{PENDAHULUAN}

Pencak silat merupakan warisan budaya Indonesia yang diwariskan secara turun temurun oleh nenek moyang bangsa Indonesia. Menurut Sucipto (2001:27) "Pencak silat adalah hasil budaya manusia Indonesia untuk membela, mempertahankan eksistensi atau kemandiriannya dan integritasnya terhadap lingkungan hidup atau alam sekitarnya untuk mencapai keselarasan hidup guna meningkatkan iman dan taqwa kepada Tuhan Yang Maha Esa.” Belajar Pencak silat tidak untuk mengelola fisik saja tetapi untuk juga mengontrol diri, emosi, mental dan mendekatkan kepada sang pencipta. Dalam pembelajaran pendidikan jasmani dan olahraga pencak silat mengembangkan karakter dan unsurunsur nilai yang terkandung didalamnya.

Pertandingan olahraga pencak silat dibagi menjadi beberapa kategori yaitu kategori jurus tunggal, kategori jurus ganda, kategori jurus beregu dan kategori tanding. Pada kategori tanding biasanya menggunakan sistem gugur. Untuk waktu pertandingan di kategori tanding untuk remaja dan dewasa berlangsung selama 3 (tiga) babak tiap babak terdiri atas 2 (dua) menit 
bersih sedangkan diantara babak diberikan waktu istirahat 1 (satu) menit. Pada persiapan untuk pertandingan kategori tanding, kondisi fisik merupakan unsur penting dan menjadi dasar atau pondasi dalam pengembangan latihan teknik, taktik, dan pengembangan mental.

Perkembangan olahraga Pencak silat di bangka belitung sudah mulai berkembang banyak para atlet meraih prestasi khusunya di bidang pencak silat antara lain O2SN, POPDA, POPWIL dan POPNAS sekarang hampir tiap sekolah sudah ada esktrakurikuler cabang olahraga pencak silat karena merupakan warisan budaya melayu.

Latihan merupakan suatu proses yang sistematik untuk meningkatkan kualitas fisik dan bertujuan untuk meningkatkan penampilan olahraga. Untuk itu metode latihan menjadi sangat penting bagi seorang pelatih. Latihan menjadi sangat efektif jika dilakukan dengan program yang baik. Kondisi fisik adalah satu kesatuan utuh dari komponen-komponen yang tidak dapat dipisahkan begitu saja. Komponen kondisi fisik tersebut terdiri atas kekuatan, kecepatan, kelincahaan, kelentukan, daya tahan, daya ledak otot, koordinasi, keseimbangan, daya lentur, dan reaksi. Dalam olahraga pencak silat kecepatan merupakan salah satu komponen penting dari kemampuan yang harus dimiliki dalam menunjang prestasi atlet. Kecepatan adalah kemampuan untuk menempuh sesuatu jarak dalam waktu sesingkat-singkatnya.

Kecepatan tendangan adalah merupakan salah satu teknik serangan pada olahraga pencak silat yang menggunakan tungkai kaki, dimana dilakukan secara berturut-turut dalam waktu yang sesingkat-singkatnya. Sedangkan tendangan sabit adalah tendangan yang dilakukan dalam lintasan setengah lingkaran. Tendangan sabit digunakan dalam menyerang atau membalas serangan, kelebihan tendangan ini mudah untuk dilakukan dalam pertandingan, ekplorasi tenaga lebih maksimum, serta jarak antara kepala dengan lawan jauh sehingga lebih aman. Kelemahan dari tendangan ini adalah jika tarikan kaki tidak cepat ditarik maka sangat mudah tendangan tersebut ditangkap. Tendangan dikatakan cepat apabila tarikan kaki saat melakukan tendangan dapat ditarik dengan cepat dan tidak nudah ditangkap oleh lawan.

Kondisi fisik sangat memberi dukungan terhadap kecepatan tendangan sabit, sehingga harus dilatih dan dikembangkan secara maksimal. Tujuannya adalah agar diperoleh hasil tendangan yang benar-benar optimal, karena metode latihan tendangan sabit yang selama ini diterapkan belum mengarah pada kecepatan tendangan yang lebih baik. Selain itu juga, terbatasnya jam latihan kurang dimanfatkan siswa secara maksimal.

Berdasarkan pengamatan peneliti di lapangan pada bulan juni 2017 di ekstrakulikuler pencak silat SMP Negeri 2 Pangkalpinang masih terdapat beberapa permasalahan, yaitu; (1) Siswa yang melakukan tendangan sabit dalam kecepatan yang belum maksimal. Hal ini terlihat dari latihan siswa pergerakan kaki masih lambat dan bisa dihindari. Dalam pertandingan pencak silat tendangan sabit merupakan teknik dasar yang mudah dilakukan dan sering digunakan orang untuk bertanding. (2) Dalam latihan siswa hanya melakukan latihan dengan menggunakan peching tanpa ada metode latihan yang bervariasi sehingga tidak ada peningkatan kecepatan tendangan, pelatih hanya melakukan latihan tendangan berulang-ulang tanpa latihan pengembangan kecepatan tendangan. Tendangan sabit yang belum cepat terlihat masih bisa dihindari dan ditangkap oleh lawan pada saat siswa bertanding, maka peneliti memberikan treatment dengan program latihan sirkuit training yang bertujuan untuk meningkatkan kecepatan tendangan.

Salah satu metode latihan yang cukup kompleks adalah metode latihan sirkuit training. Menurut Rusli Lutan, Latihan sirkuit adalah salah satu cara yang dapat memperbaiki secara serempak tingkat fitness keseluruhan dari tubuh kita yang meliputi komponen biomotorik dasar tersebut. Karena sangat kompleks dan simpel, latihan sirkuit ini sangat cocok digunakan dalam latihan ekstrakulikuler yang biasanya terkendala oleh waktu yang singkat. Jika latihan sirkuit ini dilakukan dalam waktu singkat, maka sisa waktu latihan bisa digunakan untuk berlatih teknik dan taktik secara maksimal.

Sirkuit adalah ukuran keberhasilan dalam menyelesaikan beberapa rangkaian item latihan yang berbeda-beda. Latihan sirkuit terdiri atas beberapa bentuk aktivitas komponen fisik yang terpadu dan berkesinambungan dengan membentuk pos-pos khusus. Dalam penelitian ini latihan sirkuit merupakan serangkaian latihan yang dapat dilakukan oleh siswa peserta ekstrakurikuler pencak silat SMP Negeri 2 Pangkalpinang pada suatu ruangan atau tempat terbuka dimana telah ditentukan jumlah pos sebanyak 4-5 pos dengan setiap pos dilakukan selama beberapa detik, dan repetisi sebanyakbanyaknya, waktu istirahat adalah satu menit 
sebelum melanjutkan ke pos berikutnya, latihan ini dilakukan dalam dua set.

Metode penelitian ini diharapkan agar siswa ekstrakulikuler pencak silat SMP Negeri 2 Pangkalpinang lebih tertarik dan termotivasi dalam mengikuti latihan.

Berdasarkan penjelasan di atas, peneliti ingin mengadakan penelitian yang berjudul "Pengaruh Latihan Sirkuit Training Terhadap Kecepatan Tendangan Sabit Ekstrakurikuler Pencak Silat Siswa SMP Negeri 2 Pangkalpinang."

\section{METODE}

Penellitian ini menggunakan pendekatan kuantitatif karena data penelitian berupa angka dan analisis menggunakan statistik. Metode penelitian yang digunakan adalah penelitian true eksperimental design (penelitian eksperimental yang sebenarnya).

Jenis desain yang dipakai adalah pretestposttest control group design. Dalam desain ini terdapat dua kelompok yang dipilih secara random, kemudian diberi pretest untuk mengetahui keadaan awal adakah perbedaan antara kelompok eksperimen dan kelompok kontrol. Menurut Sugiyono (2016:112) desain penelitian dapat digambarkan sebagai berikut:

\begin{tabular}{|lll|}
\hline E O & X & O$_{2}$ \\
K O O$_{1}$ & & O $_{2}$ \\
\hline
\end{tabular}

Gambar 8. Design penelitian

Keterangan :

$\mathrm{E}=$ kelompok eksperimen

$\mathrm{K}=$ kelompok kont

$\mathrm{X}=$ perlakuan dengan latihan sirkuit training

$\mathrm{O}_{1}=$ nilai pretest tes awal

$\mathrm{O}_{2}=$ nilai posttest tes akhir

Tempat untuk melakukan penelitian atau pengambilan data dalam penelitian ini direncanakan akan dilaksanakan di SMP Negeri 2 Pangkalpinang. Untuk pelaksanaan latihan yang diterapkan untuk siswa yang mengikuti ekstrakurikuler pencak silat di lapangan SMP Negeri 2 Pangkalpinang.

Waktu yang digunakan dalam penelitian terhitung bulan oktober sampai dengan november 2017. Kegiatan dilakukan selama 5 minggu dengan 16 kali pertemuan perlakuan latihan, 1 kali pretest dan 1 kali posttest. Kegiatan dilakukan mulai dari pengamatan, tes awal, pemberian metode latihan, dan tes akhir. Waktu latihan dilakukan 4 kali dalam seminggu dimulai dari hari senin, selasa, jum'at dan sabtu sore jam 16.00 - 17.30 WIB.

Populasi dan sampel sering digunakan dalam penelitian kuantitatif. Populasi menunjukan subjek atau objek data yang akan menjadi sumber penelitian di suatu wilayah. Populasi di dalam penelitian ini adalah seluruh siswa yang mengikuti kegiatan ekstrakurikuler pencak silat di SMP Negei 2 Pangkalpinang. Siswa yang mengikuti ekstrakurikuler tersebut adalah siswa yang berjumlah 28 orang.

Sementara itu, sampel merupakan bagian dari populasi. Teknik pengambilan sampel dalam penelitian ini menggunakan total sampling adalah teknik penentuan sampling apabila semua anggota populasi digunakan sebagai sampel. Hal ini sering dilakukan apabila jumlah populasi relatif kecil atau kurang dari 30 atau peneliti ingin membuat generasi dengan derajat kesalahan yang sangat kecil. Untuk menentukan kelompok eksperimen dan kelompok kontrol yaitu dengan menggunakan teknik ordinal pairing. Sampel terdiri dari 28 orang dibagikan dua kelompok yaitu 14 orang kelompok eksperimen dan 14 orang kelompok kontrol. Kelompok eksperimen diberi perlakuan dan kelompok kontrol tidak diberi perlakuan.

Penelitian ini adalah penelitian yang menggunakan metode eksperimen dengan latihan sirkuit training sebagai variabel bebas dan kecepatan tendangan sabit sebagai variabel terikat. Data yang akan dikumpulkan dalam penelitian ini, yaitu: (1). Data pre-test hasil tes kemampuan kecepatan tendangan sabit dengan menggunakan pengukuran kecepatan tendangan sabit sebelum sampel diberikan perlakuan atau treatment, (2). Data post-test hasil tes kemampuan kecepatan tendangan sabit dengan menggunakan pengukuran kecepatan tendangan sabit setelah sampel diberikan perlakuan atau treatment dengan menggunakan metode latihan sirkuit training.

Pengujian validitas pada penelitian ini penguji menggunakan validitas konstruk (construct validity). Instrumen kecepatan tendangan sabit ini telah divalidasi oleh 3 orang yang ahli dalam bidang olahraga pencak silat dan menyatakan instrumen kecepatan tendangan sabit layak untuk digunakan sebagai alat pengumpul data pada penelitian ini.

Pengujian reliabilitas instrumen dilakukan dengan internal consistency dilakukan dengan cara mencobakan instrumen sekali saja dengan 
teknik test-retest. Tahapan perhitungan uji reabilitas dengan menggunakan teknik testretest.

Dalam penelitian kuantitatif, analisis data merupakan kegiatan setelah data dari seluruh responden atau sumber lain terkumpul. Menurut Sugiono (2007:207) kegiatan analisis data adalah mengelompokkan data berdasarkan variabel dan jenis responden, mentabulasi data berdasarkan variabel dari seluruh responden, menyajikan data tiap variabel yang diteliti, melakukan perhitungan untuk menguji hipotesis yang telah diajukan.

Untuk menguji normalitas data digunakan statistika uji Kolmogorov-Smirnov dengan taraf signifikan $\alpha=0,050$.

Untuk menguji homogenitas variansi distribusi skor pretest postest, maka digunakan uji $\mathrm{F}$ (nilai Fisher) dengan rumus sebagai berikut:

$$
F=\frac{S^{2} \text { terbesar }}{S^{2} \text { terkecil }}
$$

Keterangan:

$S^{2}$ terbesar = Nilai varian terbesar

$S^{2}$ terkecil = Nilai varian terkecil.

Untuk menguji hipotesis yang diajukan, maka peneliti menggunakan rumus T-Test (Prettes-Posttes) Uji Beda Dua Mean Data tidak Berpasangan.

\section{HASIL DAN PEMBAHASAN}

Pretest digunakan sebagai acuan apakah siswa yang dijadikan sampel setelah diberi perlakuan mengalami peningkatan hasil kecepatan tendangan sabit. Sedangkan Postest dilakukan untuk melihat apakah hasil kecepatan tendangan sabit meningkat setelah siswa diajarkan dengan menggunakan metode latihan sirkuit training. Adapun data hasil siswa (hasil Pretest-Postest).

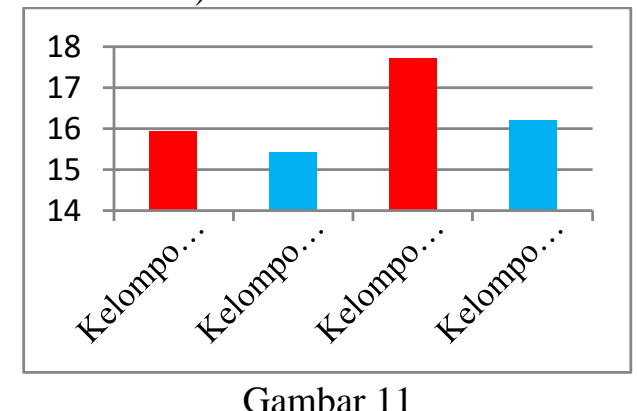

Grafik Perbedaan Pretest dan Postest Kelompok Eksperimen dan Kelompok Kontrol
Berdasarkan tabel dan grafik perbedaan mean pretest - posttest kelompok eksperimen dan kelompok kontrol dapat disimpulkan, terjadi peningkatan mean sebesar 2\%. Sedangkan pretest - posttest kelompok kontrol mengalami peningkatan sebesar 1\%. Dengan demikian kelompok posttest eksperimen lebih baik dari posttest kelompok kontrol. Jadi metode latihan sirkuit training berpengaruh positif terhadap kecepatan tendangan sabit pada peserta ekstrakurikuler di SMP Negeri 2 Pangkalpinang.

Hasil pengujian normalitas data disajikan sebagai berikut:

Tabel 3

Rekapitulasi Hasil Uji Normalitas

\begin{tabular}{|c|c|r|r|c|}
\hline Kelompok & Tes & Dhitung & Dtabel & Ket \\
\hline \multirow{2}{*}{ Eksperimen } & Pretest & 0,170 & & Normal \\
\cline { 2 - 3 } \cline { 5 - 5 } & Postest & 0,179 & \multirow{3}{*}{0,258} & Normal \\
\hline \multirow{2}{*}{ Kontrol } & Pretest & 0,197 & & Normal \\
\cline { 2 - 3 } \cline { 5 - 5 } & Postest & 0,224 & & Normal \\
\hline
\end{tabular}

Berdasarkan tabel di atas, bahwa dengan $\mathrm{D}_{\text {tabel }}$ pada peserta didik dengan tingkat alfa $5 \%$ maka diperoleh $\mathrm{D}_{\text {tabel }} 0,258$. Hasil perhitungan manual kelas eksperimen nilai pretest $\mathrm{D}_{\text {hitung }}$ 0,170 sehingga $\mathrm{D}_{\text {hitung }} 0,170<\mathrm{D}_{\text {tabel }} 0,258$, dan nilai posttest $\mathrm{D}_{\text {hitung }} 0,179$ sehingga $\mathrm{D}_{\text {hitung }} 0,179<$ $\mathrm{D}_{\text {tabel }}$ 0,258. Untuk kelas kontrol nilai pretest $\mathrm{D}_{\text {hitung }} 0,197$ sehingga $\mathrm{D}_{\text {hitung }} 0,197<\mathrm{D}_{\text {tabel }} 0,258$, dan nilai posttest $\mathrm{D}_{\text {hitung }} 0,224$ sehingga $\mathrm{D}_{\text {hitung }}$ $0,224<\mathrm{D}_{\text {tabel }} 0,258$. Maka dapat disimpulkan bahwa data berasal dari populasi yang berdistribusi normal. Kemudian hasil perhitungan SPSS 16.0 kelompok eksperimen nilai pretest dengan signifikannya $0,200>0,05$ dan postest $0,200>0,05$ dan untuk kelompok kontrol nilai pretest dengan signifikannya 0,146>0,05 dan postest 0,056>0,05 maka populasi yang yang digunakan untuk penelitian berdistribusi normal.

Hasil pengujian homogenitas data disajikan sebagai berikut:

Tabel 4

Rekapitulasi Hasil Uji Homognitas

\begin{tabular}{|c|c|c|c|}
\hline Kelompok & $\begin{array}{c}\mathrm{F} \\
\text { hitung }\end{array}$ & $\begin{array}{c}\mathrm{F} \\
\text { tabel }\end{array}$ & Keterangan \\
\hline Pretest & 1,132 & 2,576 & Homogen \\
\hline Postest & 2,149 & 2,576 & Homogen \\
\hline
\end{tabular}

Berdasarkan tabel di atasdiperoleh nilai pretest $\mathrm{F}_{\text {hitung }} 1,132$ dan nilai postest $\mathrm{F}_{\text {hitung }} 2,149$. $\mathrm{F}_{\text {hitung }}<\mathrm{F}_{\text {tabel }}$ yakni 1,132 dan 2,149<2,576, maka 
dapat disimpulkan bahwa penelitian baik pretest maupun postest berasal dari varian homogen.

Berdasarkan pengujian hiporesis perhitungan diketahui bahwa $t_{\text {hitung }}=3,483>t_{\text {tabel }}$ $=2,056$, maka dapat disimpulkan bahwa terdapat pengaruh latihan sirkuit training terhadap kecepatan tendangan.

Setelah semua data dianalis dengan berbagai tahapan yang dimulai dengan uji statistika untuk menentukan mean, median, modus, standar deviasi, varian dan range. Kemudian dilakukan uji normalitas data untuk mengetahui apakah data berdistribusi normal atau tidak dan ternyata didapatkan hasil untuk keseluruhan nilai yang diperoleh setelah dilakukan perhitungan menyatakan bahwa semua data berdistibusi normal. Berdasarkan hasil perhitungan uji normalitas secara manual menggunakan uji Kolmogorov-Smirnov dengan kriteria $\mathrm{D}_{h}<\mathrm{D}_{t}$ maka dapat disimpulkan bahwa data berdistribusi normal, sedangkan $\mathrm{D}_{h}>\mathrm{D}_{t}$ maka dapat disimpulkan bahwa data berdistribusi tidak normal. Selanjutnya diperoleh data pada kelompok eksperimen nilai pretest dengan signifikannya $0,200>0,05$ dan postest $0,200>$ 0,05 dan untuk kelompok kontrol nilai pretest dengan signifikannya $0,146>0,05$ dan postest $0,056>0,05$ maka populasi yang yang digunakan untuk penelitian berdistribusi normal.

Selanjutnya dilakukan uji homogenitas untuk mengetahui data berasal dari populasi yang homogenatau tidak. Berdasarkan peritungan yang telah dilakukan diperoleh nilai pretest $\mathrm{F}_{\text {hitung }}$ 1,132 dan nilai postest $F_{\text {hitung }} 2,149$. $F_{\text {hitung }}<F_{\text {tabel }}$ yakni 1,132 dan $2,149<2,576$, maka dapat disimpulkan bahwa penelitian baik pretest maupun postest berasal dari varian homogen. Setelah data telah dinyatakan normal dan homogen maka dapat dilakukan analisis terakhir. Analisis terakhir yang dilakukan adalah uji hipotesis dengan syarat $t_{\text {hitung }}$ lebih besar dari $t_{\text {tabel. }}$. Hasil yang diperoleh yaitu, $t_{\text {hitung }} 3,483>t_{\text {tabel }}$ 2,056 yang bearti $\mathrm{H}_{0}$ ditolak dan $\mathrm{H}_{\mathrm{a}}$ diterima. Maka dapat dinyatakan bahwa terdapat pengaruh latihan sirkuit training terhadap kecepatan tendangan sabit pada siswa ekstrakurikuler pencak silat SMP Negeri 2 Pangkalpinang.

Berdasarkan hasil analisis pelaksanaan penelitian, hasil penelitian dan pembahasan, maka dapat disimpulkan bahwa pada penelitian ini menyatakanbahwa melalui latihan sirkuit training mampu meningkatan hasil kecepatan tendangan siswa.

\section{SIMPULAN DAN SARAN}

Berdasarkan hasil penelitian dapat disimpulkan, bahwa pada hasil uji hipotesis dengan syarat $t_{\text {hitung }}$ lebih besar dari $t_{\text {tabel. }}$. Hasil yang diperoleh yaitu, $t_{\text {hitung }} 3,483>t_{\text {tabel }} 2,056$ yang berarti terdapat pengaruh positif latihan sirkuit training terhadap kecepatan tendangan sabit pada siswa ekstrakurikuler pencak silat SMP Negeri 2 Pangkalpinang.

Berdasarkan hasil penelitian, implikasi dalam penelitian ini sebagai berikut:

1. Hasil penelitian mengenai pengaruh latihan sirkuit training terhadap kecepatan tendangan sabit pada siswa ekstrakulikuler pencak silat meunjukan adanya pengaruh dari kedua variabel tersebut.

2. Metode latihan sirkuit training dapat dijadikan alternatif atau variasi dalam proses latihan di ekstrakulikuler sehingga kegiatan ekstrakulikuler menjadi aktif dan menyenangkan serta mampu mengembangkan sikap percaya diri, kerja sama dan melatih kecepatan tendangan sabit siswa.

Ada beberapa saran yang perlu disampaikan sehubungan dengan hasil penelitian ini, antara lain:

1. Bagi siswa, harus selalu meningkatkan semangat latihan dan mengikuti instruksi pelatih agar program latihan yang dirancang pelatih dapat tercapai dengan baik dan juga dapat meningkatkan kualitas serta menunjang siswa agar bisa berprestasi.

2. Bagi sekolah, proses kegiatan ekstrakurikuler pencak silat harus selalu dilaksanakan karena kegiatan ini bertujuan untuk menyalurkan minat dan bakat siswa.

3. Bagi pelatih dan guru olahraga sebagai bahan pertimbangan dan referensi serta untuk memperbaiki dan meningkatkan hasil latihan.latihan kecepatan tendangan sabit dalam pencak silat tidak hanya terpaku dengan latihan tanpa objek atau sasaran, tetapi juga harus menggunakan sasaran agar siswa dapat lebih bersemangat dalam melakukan tendangan dan dengan pola latihan lebih menarik lainnya.

4. Bagi peneliti lain, penelitian ini masih perlu dikembangkan lagi, sehingga dapat memberikan informasi yang lebih banyak dan untuk melakukan penelitian selanjutnya masih perlu memperhatikan kelemahankelemahan penelitian sebelumnya. 


\section{DAFTAR RUJUKAN}

Apta, Mylsidayu, dan Febi kurniawan. 2015.Ilmu kepelatihan dasar. Bandung:

CV Alfabeta.

Depdikbud.1994. Pengertian Ekstrkurikuler.http://www.Landasanteori. com/2015/11/pengertian-ekstrakurikulerdefinisi.html. (Diakses tanggal 10 juli 2017).

Erwin, Setyo Kriswanto. 2015. Pencak Silat. Yogyakarta: Pustaka Baru Press.

G. Gregory Haff dan Tudor O. Bompa. 2015.PERIODIZATION. Bandung: CV Alfabeta.

Kusumawati,Mia. 2014. Penelitian Pendidikan Penjasorkes. Bandung: Alfabeta.

Lubis, Johansyah. 2013. Panduan praktis Penyusunan Latihan. Jakarta: PT Raja Grafindo Persada.

Lubis, Johansyah, dan Hendro Wardoyo. 2014. Pencak Silat. Jakarta: PT Raja Grafindo Persada.

Maskum, Ali. 2012. Metodologi Penelitian Dalam Olahraga. Surabaya: Unesa University Press.

Pengertian

ekstrakulikuler http://www.landasanteori.com/2015/11/pe ngertian-ekstrakurikuler-defenisi.html. (diakses 2 agustus 2017).

Pengertian tendangan Putra, Ade, 20 febuari. 2013. http://triksilat.blogspot.com/p/blogpage_5142.html. (Diakses tanggal 21 juli 2107).

Pengertian sirkuit http://nurwigiansyah.blogspot.co.id/2015/ 3/latihan-sirkuit-atau-circuittraining.html. (diakses tanggal 31 juli 2017).

Riadi, Edi, 2015. Metode Statistika: Parametrik Dan Nonparametrik. Tangerang: Pustaka Mandiri.
Sucipto. 2001. Pendekatan Keterampilan Taktis dalam Pembelajaran Pencak Silat, Jakarta Pusat: Direktrat Jendral Olahraga.

Sugiyono. 2016. Metodelogi Penelitian Pendidikan pendekatan kuantitatif, kualitatif, dan $R \& D$. Bandung: Alfabeta.

Sudijono, Anas. 2007. Evaluasi Pendidikan. Jakarta: PT Raja Grafindo Persada.

Muhyi Faruq, Muhammad. 2009. Meningkatkan Kebugaran Jasmani. Surabaya: PT Gramedia Widiasarana Indonesia. 